\title{
Design Science Approach to Management
}

\author{
Grzegorz Baran \\ Jagiellonian University in Krakow
}

\section{Introduction}

This paper introduces a model of research framing in management sciences. The model takes into account that the conventional approaches to management regarded as an explanatory science are not sufficient to fully examine and deal with contemporary ill-structured, complex, unambiguous and often open management and organization problems, especially in complex environment and uncertain conditions ${ }^{1}$.

There is a critical need for novel theorizing on emerging problems within organizations and management that does not rely only on current assumptions and enable to develop new research approaches. The purpose of this research study is to develop and present a design science approach framework for management as a relatively new approach, which derives from design sciences and is understood both as a science and practice within an organization and management field.

While it nowadays seems to derive just from design, a design science approach has been actually present in management all along ${ }^{2}$. Its significance in management research and literature has been growing since Herbert Simon's book entitled The Science of the Artificial ${ }^{3}$. It delivers a new scientific framework for the description, explanation and design innovative solutions of social, organizational and management problems.

1 H.W. Rittel, M.M. Webber, Dilemmas in a general theory of planning, "Policy Sciences" 1973, no. 4(2), pp. 155-169; R. Buchanan, Wicked Problems in Design Thinking, "Design Issues" 1992, no. 8(2), pp. 5-21; A. Koźmiński, Zarzqdzanie w warunkach niepewności, Wydawnictwo Naukowe PWN, Warszawa 2004.

2 H. Simon, The sciences of the artificial, MiT Press, Cambridge 1996; W. Gasparski, Wiedza o organizacji i zarzqddzaniu oraz jej poznawcze ugruntowanie, "Wspótczesne Zarządzanie" 2007, no. 1, pp. 34-47; J. Holmström, M. Ketokivi, A.P. Hameri, Bridging practice and theory: a design science approach, "Decision Sciences" 2009, no. 40(1), pp. 65-87. 
This research study was realized with conceptual research, wherein the existing knowledge was used as a source of reasoning leading to solve the scientific problem. It is caused by a reflective nature of the presented argument drawing on traditions of conceptual research and theoretical findings, which result from an intellectual deliberation in order to speculate within a specifiable problem domain. The method of analysis and synthesis was used to better understand this emerging and increasingly popular approach, which is still differently defined (among others as: design-led approach, design thinking, design management). Trying to answer the question, what the core of the design science approach is, and to sketch an overall framework of this approach, the fundamental reasoning patterns behind problemsolving in management were especially considered.

\section{Management as a design science}

Several authors position management among design sciences ${ }^{4}$. According to Gasparski, organizational theory or management science is a practical discipline (science) in the sense that Kotarbiński gave to this concept. He recalls Simon who referred to this family of disciplines as sciences of the artificial, distinguishing the sciences of the products of human activities from the sciences of the natural world 5 . Gasparski notes that both scientists (Simon and Kotarbiński) pointed to design as a methodological distinguishing feature of management sciences ${ }^{6}$. A similar point regarding management practice is maintained by Huff who claims that "for some time, there has been an interest in design as a primary descriptor of management practice" 7 .

Simon in The sciences of the artificial ${ }^{8}$ divided all sciences into normal/explanatory sciences and artificial/design sciences. Joan E. van Aken calls them accordingly explanatory sciences and design sciences 9 . Simon associates artificial sciences or the sciences of design with the term artificial. He claims:

4 H. Simon, The sciences...; W. Gasparski, Wiedza o organizacji...; A.G.L. Romme, Making a difference: Organization as design, "Organization Science" 2003, no. 14(5), pp. 558-573; J.E. van Aken, Management research as a design science: Articulating the research products of mode 2 knowledge production in management, "British Journal of Management" 2005, no. 16(1), pp. 19-36.

5 W. Gasparski, Wiedza o organizacji..., p. 34.

6 Ibidem.

7 A. Huff, D. Tranfield, J.E. van Aken, Management as a design science mindful of art and surprise: A conversation between Anne Huff, David Tranfield, and Joan Ernst van Aken, "Journal of Management Inquiry" 2006, no. 15(4), p. 413.

8 H. Simon, The sciences...

9 A. Huff, D. Tranfield, J.E. van Aken, Management..., p. 414. 
My dictionary defines "artificial" as, "Produced by art rather than by nature; not genuine or natural; affected; not pertaining to the essence of the matter". It proposes, as synonyms: affected, factitious, manufactured, pretended, sham, simulated, spurious, trumped up, unnatural. As antonyms, it lists: actual, genuine, honest, natural, real, truthful, unaffected. Our language seems to reflect man's deep distrust of his own products. I shall not try to assess the validity of that evaluation or explore its possible psychological roots. But you will have to understand me as using "artificial" in as neutral a sense as possible, as meaning man-made as opposed to natural ${ }^{10}$.

Simon, examining the administration, noticed that the effectiveness of the performance depends on the effectiveness of the play and the effectiveness with which it is played (the context of the actions taken). Consequently, it is impossible to construct an empirical theory of administration modeled on natural sciences. He therefore asked the question how to build such a theory that would contain more than the normative rules of good acting. He binds this problem with the problem of artificiality ${ }^{11}$. According to Simon, the world of artifacts is completely different from the natural world. As he notes:

The thesis is that certain phenomena are "artificial" in a very specific sense: they are as they are only because of a system's being moulded, by goals or purposes, to the environment in which it lives. If natural phenomena have an air of "necessity" about them in their subservience to natural law, artificial phenomena have an air of "contingency" in their malleability by environment ${ }^{12}$.

He noticed that the problem of artificiality was not specific to administration and organizations but that it infected a wider range of subjects ${ }^{13}$. He describes the results of his research as follows:

Finally, I thought I began to see in the problem of artificiality an explanation of the difficulty that has been experienced in filling engineering and other professions with empirical and theoretical substance distinct from the substance of their supporting sciences. Engineering, medicine, business, architecture, and painting are concerned not with the necessary but with the contingent not with how things are but with how they might be in short, with design. The possibility of creating a science or sciences

10 H. Simon, The sciences..., p. 4.

11 Ibidem, p. xii.

12 Ibidem, p. xi.

13 Ibidem, p. xii. 
of design is exactly as great as the possibility of creating any science of the artificial. The two possibilities stand or fall together ${ }^{14}$.

Joan E. van Aken distinguishes three major categories of scientific disciplines: (i) formal sciences, (ii) explanatory sciences and (iii) design sciences ${ }^{15}$. In the formal sciences (such as philosophy and mathematics) scientists build systems of empirically void propositions tested if they are logically consistent. The explanatory sciences (such as natural sciences and most social sciences) describe, explain and possibly predict observable phenomena within its fields. In these sciences researchers develop propositions accepted by the scientific community as true on the basis of the empirical evidence. The role of design sciences (such as engineering sciences, medical sciences, psychotherapy and a significant part of management) is to develop knowledge for the design and realization of artifacts ${ }^{16}$.

Nowadays, the fundamental reason, why a different theoretical approach to management is needed, is the problem of relevance to practice. A number of authors draw attention to the problem of relevance of the organization and management research to practice ${ }^{17}$.

Joan E. van Aken pays attention to serious doubts about the actual relevance of present management theory as developed by the academic community. Management sciences are permanently losing their chance to matter to the real world of organization and business. This is a dismal picture of those sciences if we assume that their major responsibility is the thoughtful preparation and guidance of practitioner professionals. If management scientists and researchers are to deal in a domain that vitally affects societal well-being, they have to enter the world of practice affairs to carry out valuable and useful scientific research ${ }^{18}$.

Hambrick claims that we need "bridge theory and practice"19. He develops this statement among others with the words:

\section{Ibidem.}

15 J.E. van Aken, Management research based on the paradigm of the design sciences: the quest for field-tested and grounded technological rules, "Journal of Management Studies" 2004, no. $41(2)$, p. 224.

16 Ibidem.

17 A.G.L. Romme, Making a difference...; A. Huff, D. Tranfield, J.E. van Aken, Management...; J.E. van Aken, Management research...; D. Denyer, D. Tranfield, J.E. van Aken, Developing design propositions through research synthesis, "Organization Studies" 2008, no. 29(3), pp. 393-413; D.C. Hambrick, What if the academy actually mattered?, "Academy of Management Review" 1994, no. 19(1), pp. 11-16.

18 J.E. van Aken, Management research..., pp. 219-220.

19 D.C. Hambrick, What if..., p. 13. 
It's been said that there are three kinds of people: those who make things happen, those who watch things happen, and those who wonder what happened. To a great extent, the role of a scholar is in the middle category: to observe, analyze, critique, and disseminate. This is important work, and we should never take our eyes off it. However, when an academic field has as its charge the thoughtful preparation and guidance of practitioner professionals, and when an academic field deals in a domain that vitally affects societal well-being, then that academic field must enter the world of practical affairs. Without being co-opted, it must strive for influence and impact. That is our challenge. We should matter. We must matter ${ }^{20}$.

Hambrick writes about the need for co-optation with the environment or practice domain which resembles Simon's category of the contingency of artificial phenomena in their malleability by environment. The results of management research are being continuously molded not only by research purposes but also by the context, which delivers the framework that enables the interpretation of these results. Thus, management sciences are suggested to open up the closed loop of management academic community to the outside world, the world of practice ${ }^{21}$. However, it is not easy because, as van Aken remarks:

Management theory is either scientifically proven, but then too reductionistic and hence too broad or too trivial to be of much practical relevance, or relevant to practice, but then lacking sufficient rigorous justification ${ }^{22}$.

Similar conclusions are delivered by the conversation between Huff, Tranfield, and van Aken entitled Management as a design science mindful of art and surprise (2006). Tranfield claims that the main reason to accept the design perspective for management field is that it might increase the relevance of research results to practice $^{23}$. According to him, it is also important in terms of establishing a strong management identity within the social sciences. The management sciences need a shared sense of purpose and specified boundaries, as well as clarified quality criteria ${ }^{24}$. Such a lack of shared purpose, identity and policy of management sciences pushes them to the margins of not only management practice but also social sciences.

Taking the all above into consideration, it seems to be essential to build a new synthesis of the existing achievements of management sciences from the

20 Ibidem, p. 16.

21 J.E. van Aken, Management research..., p. 220.

22 Ibidem, p. 221.

23 A. Huff, D. Tranfield, J.E. van Aken, Management..., p. 415.

24 Ibidem. 
perspective of design science approach assumptions. For Romme remarks, "in view of the persistent relevance gap between theory and practice, organization studies should be broadened to include design as one of its primary modes of engaging in research" 25 . Therefore, in the following chapters two conceptual paths will be presented: 1) regarding management practice in the form of rapidly developing design-led approach to management and innovation, and 2) design science research assumptions. This is a sketch of conceptual framework as a starting point for further conceptual research, what requires a deeper analysis and a broader description.

\section{Design-led approach}

Considering how Kotarbinski outlined the essence and boundaries of the theory of organization, reflection on the subject of research in contemporary management sciences seems absolutely necessary. According to Gasparski and Kotarbiński gave the following answers to the question, what is under the term organization theory ${ }^{26}$ :

- The subject of organization theory includes positively cooperating teams.

- The reference for the organization theory is to indicate the conditions of the effective performance of tasks for which the teams cooperate.

- The word organization means both an examined subject as an organized thing (which is a cooperating team) and the way of organizing (that is the structure/construction of the organized things).

The above statements can be a good starting point for further research on the analytical sense of the design-led approach to management understood as problem-solving activity. It is in line with the van Aken's observation that management practice is "the art of getting things done by people" 27 . Because managers often do what they do acting directly on the basis of their tacit knowledge, intuition and creativity, without much reflection or design ${ }^{28}$, management sciences need deliver a solid design framework for the action.

At the same time, as argued above, design as an approach to both management science and practice is not new ${ }^{29}$. Its significance in management research and

25 A.G.L. Romme, Making a difference..., p. 558.

26 W. Gasparski, Wiedza o organizacji..., p. 35.

27 A. Huff, D. Tranfield, J.E. van Aken, Management..., p. 413.

28 Ibidem.

29 H. Simon, The sciences...; W. Gasparski, Wiedza o organizacji...; J. Holmström, M. Ketokivi, A.P. Hameri, Bridging practice and theory...;A.G.L. Romme, Making a difference...; R.F. Shangraw Jr., M.M. Crow, E.S. Overman, Public administration as a design science, "Public Administration Review" 1989, no. 49(2), pp. 153-158; R. Verganti, Design, meanings, and radical 
literature has been growing since Simon's book entitled The Science of the Artificial $^{30}$. As Holmström, Ketokivi, and Hameri claim, this is among others because of that the goal of making academic research relevant to the practice remains elusive $^{31}$. According to van Aken, "there are serious doubts about the actual relevance of present-day management theory as developed by the academic community" 32 . Consequently, design has been gaining much attention among practitioners and scholars in the area of management and product development, business performance, and innovation management. These contributions are building a more grounded theoretical basis to the field of design management ${ }^{33}$.

Several authors make no distinction between a design-led approach and gaining popularity design thinking 34 . While design thinking seems be a way of reasoning and acting in practice within problem-solving ${ }^{35}$, design-led approach adapts this way of reasoning as a conceptual framework to describe and explain the processes of design thinking as empirical phenomena and refers to an emerging research agenda ${ }^{36}$. There is no use of such distinction in this paper, and both terms are treated interchangeably and complementary.

Bucolo, Wrigley, and Matthews claim that:

[...] the value that design thinking brings to an organization is a different way of framing situations and possibilities, doing things, and tackling problems: essentially a cultural transformation of the way it undertakes its business ${ }^{37}$.

innovation: A metamodel and a research agenda, "Journal of Product Innovation Management" 2008, no. 25(5), pp. 436-456.

30 H. Simon, The sciences...

31 J. Holmström, M. Ketokivi, A.P. Hameri, Bridging practice and theory...

32 J.E. van Aken, Management research..., p. 219.

33 R. Verganti, Design, meanings...

34 S. Bucolo, J.H. Matthews, Using a design led disruptive innovation approach to develop new services: practicing innovation in times of discontinuity, [in:] Proceedings of the 11th International CINet Conference: Practicing Innovation in the Times of Discontinuity, September 5-7, 2010, Zurich, pp. 176-187; S. Bucolo, C. Wrigley, Using a design led approach to emotional business modelling, [in:] Leading innovation through design: Proceedings of the DMI 2012 International Research Conference, August 8-9, 2012, Boston, pp. 323-333; S. Bucolo, C. Wrigley, J. Matthews, Gaps in organizational leadership: linking strategic and operational activities through design-led propositions, "Design Management Journal” 2012, no. 7(1), pp. 18-28.

35 L. Kimbell, Rethinking design thinking: Partl, "Design and Culture" 2011, no. 3(3), pp. 285-306; D. Kelley, T. Kelley, Twórcza odwaga, Wydawnictwo MT Biznes, Warszawa 2015; M. Wszołek, M. Grech, Komentarz do wydania II, [in:] T. Brown (ed.), Zmiana przez design: Jak Design Thinking zmienia organizacje i pobudza innowacyjność, Instytut Dziennikarstwa i Komunikacji Społecznej Uniwersytetu Wrocławskiego, Wrocław 2016, s. 11-20.

36 S. Bucolo, C. Wrigley, Using a design led...

37 S. Bucolo, C. Wrigley, J. Matthews, Gaps in organizational leadership..., p. 18. 
Design led approach is a bridge that links traditionally understood design (as a way of reasoning ant tackling problems) with management and social sciences, and fills up the gap between science and practice ${ }^{38}$. This is possible for the reason that design can be thought as a liberal art of technological culture ${ }^{39}$. Design understood like that is regarded as integrative and supple discipline, amenable to radically different interpretations in science and practice ${ }^{40}$.

By using placements to discover or invent a working hypothesis within certain settings, design enable to establish a principle of relevance for available knowledge from the science, determining how such knowledge may be useful not only in a specific context but also in the more general category of cases ${ }^{41}$. As Buchanan says:

[...] in effect, the working hypothesis that will lead to a particular product is the principle of relevance guiding the efforts of designers to gather all available knowledge bearing on how a product is finally planned ${ }^{42}$.

According to Bason, design proved to have not one, but many shapes. He recalls Buchanan's findings that:

[...] design affects contemporary life in at least four areas: symbolic and visual communication, the design of material objects (construction), design of activities and organized services (strategic planning), and finally the design of complex systems or environments for living, working, playing and learning (systemic integration) ${ }^{43}$.

As a result of being so integrative and supple, design can be an effective approach to creative, innovative and systematic ways of solving open, complex and unambiguous management problems ${ }^{44}$. Through triggering, intensifying and sustain-

38 A. Huff, D. Tranfield, J.E. van Aken, Management...; J.E. van Aken, Management research...; S. Bucolo, C. Wrigley, Using a design led...

39 R. Buchanan, Wicked Problems..., p. 5.

40 Ibidem, p. 19.

41 Ibidem, p. 18.

42 Ibidem.

43 C. Bason, Designing co-production: Discovering new business models for public services, [in:] Leading Innovation through Design Proceedings of the DMI 2012 International Research Conference, Boston 2012, pp. 311.

44 J.Liedtka, T. Ogilvie, Designing forgrowth, Columbia University Press, New York2011; T. Brown, Zmiana przez design: Jak Design Thinking zmienia organizacje i pobudza innowacyjność, Instytut Dziennikarstwa i Komunikacji Społecznej Uniwersytetu Wrocławskiego, Wrocław 2016. 
ing creativity in almost all areas of human life ${ }^{45}$, design is thought as an approach, methodology or even philosophy of creative thinking and doing, and is currently used to solve a wide range of problems ${ }^{46}$.

\section{Design Science Research}

As aforesaid, according to Holmström, Ketokivi, and Hameri, the goal of making academic research relevant to the practice remains elusive. This is because theoretical and academic research interests do not coincide with the interests of managerial practice. Looking at this fundamental challenge through the lens of design science, it gives an opportunity that problem-solving research of practice and theory-oriented academic research can complement one another ${ }^{47}$. Therefore, management research mission should be developing valid knowledge to support thoughtful, designing practitioners ${ }^{48}$. As van Aken remarks:

In an explanatory science, one is interested in "what is"; in a design science one is interested in "what can be" to solve a problem or to improve performance. Questions with respect to "what is" lead to descriptive knowledge; questions with respect to "what can be" lead to prescriptive knowledge. If in management research we undertook more research on the basis of the design sciences paradigm, we would produce more prescriptive knowledge ${ }^{49}$.

Cross writes about a desire to "scientise" design, which date back to the 20thCentury modern movement of design, and those aspirations surfaced strongly again in the "design methods movement" 50 . These inquiries, which can be traced to the early 1920 s, were in some way summed up by the aforementioned work of Simon entitled The sciences of the artificial 51 , where Simon outlined his plea for

45 D.R. Sobota, P. Szewczykowski, Design thinking jako metoda twórczości, "Filo-Sofija" 2014, no. 14(27), p. 92.

46 T. Brown, Zmiana przez design...; K. Dorst, The core of 'design thinking' and its application, "Design Studies" 2011, no. 32(6), pp. 521-532; U. Johansson-Sköldberg, J. Woodilla, M. Çetinkaya, Design thinking: past, present and possible futures, "Creativity and Innovation Management” 2013, no. 22(2), pp. 121-146; D.R. Sobota, P. Szewczykowski, Design thinking...

47 J. Holmström, M. Ketokivi, A.P. Hameri, Bridging practice and theory...

48 A. Huff, D. Tranfield, J.E. van Aken, Management..., p. 413.

49 Ibidem.

50 N. Cross, Designerly ways of knowing: Design discipline versus design science, "Design Issues" 2001, no. 17(3), p. 49.

51 H. Simon, The sciences... 
the development of a science design in the universities as "a body of intellectually tough, analytic partly formalizable, partly empirical, teachable doctrine about the design process" 52 .

In this way, design understood as inextricably tied practice and science, action and research can be useful for many domains of human activity and scientific disciplines; among others for management. The quotation from Alexander perfectly shows the difference between science and design, and at the same time this gap in management sciences, which as practical sciences they are obliged to fill: "Scientists try to identify the components of existing structures, designers try to shape the components of new structures"53.

As Gregory rightly says:

The scientific method is a pattern of problem-solving behavior employed in finding out the nature of what exists, whereas the design method is a pattern of behavior employed in inventing things....which do not yet exist. Science is analytic; design is constructive ${ }^{54}$.

Design regarded in this way is rather a research perspective, orientation or paradigm of other disciplines (including management) than a separate scientific discipline. A key element of that methodological and epistemological frame is not associating design with the artificial as produced by human not by nature (as claimed by Simon).

While taking a different frame, we do not have to give up the pursuit of scientific discovery in design sciences. In design perspective, it is usually assumed that the world of artifacts is determined by other rules than the natural world. In design sciences, there are rather technological/practical rules than natural laws ${ }^{55}$. As Gasparski says, an important point is the issue of the methodological status of these rules in management sciences, which in his opinion are not scientific laws, although sometimes they are so called. Nevertheless, they should meet empirical and theoretical tests, and their validity should be confirmed by practical effectiveness and presupposed nomological sentences in social sciences ${ }^{56}$.

52 N. Cross, Designerly ways of knowing..., p. 50.

53 C. Alexander, Notes on the Synthesis of Form (Vol. 5), Harvard University Press, Cambridge 1964, quoted in: N. Cross, Designerly ways of knowing..., p. 51.

54 S. Gregory, A Design Science, [in:] S.A. Gregory (ed.), The Design Method, Butterworth, London 1966, quoted in: N. Cross, Designerly ways of knowing..., p. 51.

55 H. Simon, The sciences...; W. Gasparski, Wiedza o organizacji...; J.E. van Aken, Management research...

56 W. Gasparski, Wiedza o organizacji..., p. 37. 
However, it does not necessarily mean that we are not able to discover such rules. We just need to recognize their different status, not only methodological but above all ontological. First, they are not laws that exist regardless of the context. However, they do exist. Secondly, as Simon ${ }^{57}$ said, they determine not what necessary but what contingent; contingent not with how things are but with how they might be. Consequently, seemingly inventing things which do not yet exist, we discover novel technological rules; novel in this sense that they are still unknown to us.

Such an epistemological frame tells us to adopt a different methodological perspective in which research is carried out through design. An important quality for adapting this approach to management is utility as a benchmark for both practice and research in the case of design sciences. As Hevner et al. say, "the goal of behavioral science research is truth. The goal of design science research is utility" 58 . They developed a promising proposal for research through design in the Information Systems field 59 .

The paradigm proposed by Hevner et al. is based on three cycles: the cycle of relevance, the cycle of design and the cycle of rigor 60 . The design cycle as the construction and evaluation of design artifacts and processes is central for design science research. The relevance cycle brings requirements from the contextual environment into the research process and enable to test the research artifacts within the environment. As a result of the rigor cycle, on the one hand, grounding theories and methods along with domain experience and expertise from the foundations knowledge base are used in the research, on the other hand the theories, methods and knowledge base are enriched as a result of the research ${ }^{61}$. Hevner underlines that "the recognition of these three cycles in a research project clearly positions and differentiates design science from other research paradigms"62. In this proposition, "truth and utility are inseparable. Truth informs design and utility informs theory" 63 .

57 H. Simon, The sciences...

58 A.R. Hevner et al., Design science in information systems research, "MIS Quarterly" 2004, no. 28(1), p. 80.

59 Ibidem; A.R. Hevner, A Three Cycle View of Design Science Research, "Scandinavian Journal of Information Systems" 2007, no. 19(2), pp. 87-92.

60 A.R. Hevner et al., Design science...; A.R. Hevner, A Three Cycle...

61 A.R. Hevner, A Three Cycle...

62 Ibidem, p. 87.

63 A.R. Hevner et al., Design science..., p. 80. 
Environment

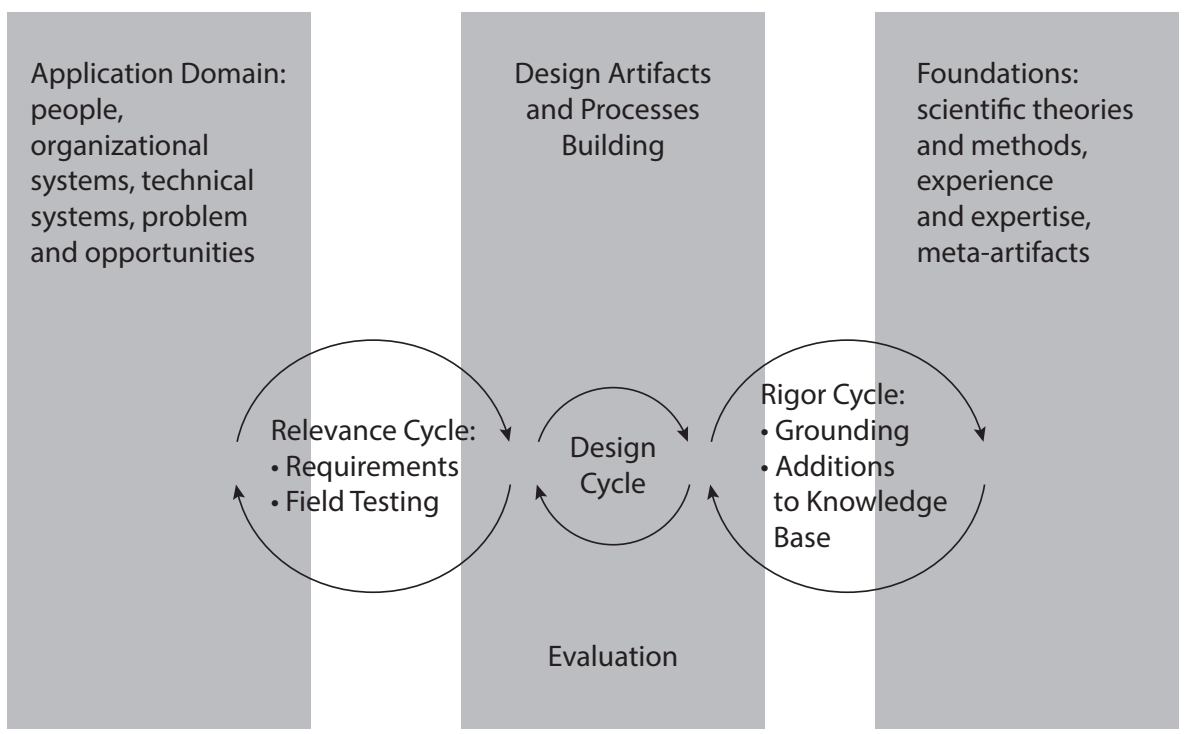

Figure 1. Design Science Research Cycles

Source: A.R. Hevner, A Three Cycle View of Design Science Research, "Scandinavian Journal of Information Systems" 2007, no. 19(2), p. 88.

As Hevner rightly claims, this proposal is essential not only among Information Systems professionals but also for the larger body of design science researchers in the various fields ${ }^{64}$. According to Peffers et al., such research need a strong component capable of producing explicitly applicable research solutions, what is an important value in design science disciplines ${ }^{65}$. Consequently, as Weber emphasizes, the challenge of design science research is to "generate scientifically sound new knowledge while producing relevant research results that can be used by practitioners at the same time" 66 . The proposed research paradigm seems to respond to such a challenge. However, this paradigm "has proven to produce practically relevant research results but is still not a fully accepted research approach since it has somehow failed to develop theoretical contributions" 67 .

64 A.R. Hevner, A Three Cycle..., pp. 87-88.

65 K. Peffers et al., A design science research methodology for information systems research, "Journal of Management Information Systems" 2007, no. 24(3), pp. 45-77.

66 S. Weber, Design science research: Paradigm or approach?, [in:] Proceedings of the Sixteenth Americas Conference on Information Systems, no. 214, Lima 2010.

67 Ibidem. 


\section{Conclusions}

Management sciences have been all along found among design sciences (besides formal sciences and explanatory sciences) by some authors ${ }^{68}$. They point to design as a methodological distinguishing feature of management sciences and a primary descriptor of management practice. The role of explanatory sciences (such as natural sciences and most social sciences) is to describe, explain and possibly predict observable phenomena within its fields. The role of design sciences is to develop knowledge for the design and accomplishment of artifacts and processes ${ }^{69}$. Without considering this fact and striving to achieve the ideal of explanatory sciences, the problem of relevance of the organization and management research to practice deepens.

That is the fundamental reason, why a different theoretical approach to management is needed. Thus, the base of knowledge of management studies needs to be expanded to include design as one of its primary modes of engaging in research ${ }^{70}$. Consequently, the sketch of the conceptual framework of such an approach was presented in this paper; as a starting point for further conceptual research. Two paths for incorporating the design perspective into management sciences have been revealed: 1) design-led approach to management and innovation, and 2) design science research paradigm/approach.

Design-led approach is based on the assumption that management practice is the art of getting things done, and consequently management sciences need deliver a solid design framework for the action for managers, who often do what they do acting directly on the basis of their tacit knowledge ${ }^{71}$. Design brings to an organization a different way of framing situations and possibilities, doing things, and tackling problems ${ }^{72}$. As an integrative and supple discipline, design proved to be effective in solving open, complex and unambiguous management problems, and it is now regarded as an approach, methodology or even philosophy of creative thinking and doing, used to solve a wide range of problems ${ }^{73}$.

Design as the research framework allows to establish a principle of relevance for available knowledge from the science, determining how such knowledge may

68 H. Simon, The sciences...; W. Gasparski, Wiedza o organizacji...; A.G.L. Romme, Making a difference...; J.E. van Aken, Management research...

69 J.E. van Aken, Management research...

70 A.G.L. Romme, Making a difference...

71 A. Huff, D. Tranfield, J.E. van Aken, Management...

72 S. Bucolo, C. Wrigley, J. Matthews, Gaps in organizational leadership...

73 K. Dorst, The core of 'design thinking'...; U. Johansson-Sköldberg, J. Woodilla, M. Çetinkaya, Design thinking... 
be useful not only in a specific context but also in the more general category of cas$\mathrm{es}^{74}$. For such a research a different frame is needed, which is based rather on technological/practical rules than natural laws ${ }^{75}$. Such rules have different ontological and methodological status than this of natural laws. They do not exist regardless of the context and determine not what is necessary but what is contingent with how things might be. While inventing things which do not yet exist, we discover novel technological rules contingent with the contextual environment. Such an epistemological frame needs to adopt a different methodological perspective in which research is carried out through design.

A promising proposal for research through design has been developed by Hevner et al. in the Information Systems field 76 . The substance of this proposal encompasses three closely related cycles of research activities: the cycle of relevance, the cycle of design and the cycle of rigor ${ }^{77}$. While the design cycle is based on the construction and evaluation of design artifacts and processes, the other two cycles allow interaction with the contextual environment and the scientific knowledge base. This enables researchers both to produce explicitly applicable research solutions and develop theoretical contributions.

\section{References}

Aken J.E. van, Management research as a design science: Articulating the research products of mode 2 knowledge production in management, "British Journal of Management" 2005, no. 16(1), pp. 19-36.

Aken J.E. van, Management research based on the paradigm of the design sciences: the quest for field-tested and grounded technological rules, "Journal of Management Studies" 2004, no. 41(2), pp. 219-246.

Alexander C., Notes on the Synthesis of Form (Vol. 5), Harvard University Press, Cambridge 1964. Bason C., Designing co-production: Discovering new business models for public services, [in:] Leading Innovation through Design Proceedings of the DMI 2012 International Research Conference, Boston 2012, pp. 309-322.

Brown T., Zmiana przez design: Jak Design Thinking zmienia organizacje i pobudza innowacyjność, Instytut Dziennikarstwa i Komunikacji Społecznej Uniwersytetu Wrocławskiego, Wroctaw 2016.

Buchanan R., Wicked Problems in Design Thinking, "Design Issues" 1992, no. 8(2), pp. 5-21.

Bucolo S., Matthews J.H., Using a design led disruptive innovation approach to develop new services: practicing innovation in times of discontinuity, [in:] Proceedings of the 11th International

74 R. Buchanan, Wicked Problems...

75 H. Simon, The sciences...; W. Gasparski, Wiedza o organizacji...; J.E. van Aken, Management research...

76 A.R. Hevner et al., Design science...; A.R. Hevner, A Three Cycle...

77 Ibidem. 
CINet Conference: Practicing Innovation in the Times of Discontinuity, September 5-7, 2010, Zurich, pp. 176-187.

Bucolo S., Wrigley C., Using a design led approach to emotional business modelling, [in:] Leading innovation through design: Proceedings of the DMI 2012 International Research Conference, August 8-9, 2012, Boston, pp. 323-333.

Bucolo S., Wrigley C., Matthews J., Gaps in organizational leadership: linking strategic and operational activities through design-led propositions, "Design Management Journal" 2012, no. $7(1)$, pp. 18-28.

Cross N., Designerly ways of knowing: Design discipline versus design science, "Design Issues" 2001, no. 17(3), pp. 49-55.

Denyer D., Tranfield D., Aken J.E. van, Developing design propositions through research synthesis, "Organization Studies" 2008, no. 29(3), pp. 393-413.

Dorst K., The core of 'design thinking' and its application, "Design Studies" 2011, no. 32(6), pp. 521-532.

Gasparski W., Wiedza o organizacji i zarzq̨dzaniu oraz jej poznawcze ugruntowanie, "Współczesne Zarządzanie" 2007, no. 1, pp. 34-47.

Gregory S., A Design Science, [in:] S.A. Gregory (ed.), The Design Method, Butterworth, London 1966.

Hambrick D.C., What if the academy actually mattered?, "Academy of Management Review" 1994, no. 19(1), pp. 11-16.

Hevner A.R., A Three Cycle View of Design Science Research, "Scandinavian Journal of Information Systems" 2007, no. 19(2), pp. 87-92.

Hevner A.R., March S.T., Park J., Ram S., Design science in information systems research, "MIS Quarterly" 2004, no. 28(1), pp. 75-105.

Holmström J., Ketokivi M., Hameri A.P., Bridging practice and theory: a design science approach, "Decision Sciences" 2009, no. 40(1), pp. 65-87.

Huff A., Tranfield D., Aken J.E. van, Management as a design science mindful of art and surprise: A conversation between Anne Huff, David Tranfield, and Joan Ernst van Aken, "Journal of Management Inquiry" 2006, no. 15(4), pp. 413-424.

Johansson-Sköldberg U., Woodilla J., Çetinkaya M., Design thinking: past, present and possible futures, "Creativity and Innovation Management" 2013, no. 22(2), pp. 121-146.

Kelley D., Kelley T., Twórcza odwaga, Wydawnictwo MT Biznes, Warszawa 2015.

Kimbell L., Rethinking design thinking: Part I, “Design and Culture” 2011, no. 3(3), pp. 285-306.

Koźmiński A., Zarzq̨dzanie w warunkach niepewności, Wydawnictwo Naukowe PWN, Warszawa 2004.

Liedtka J., Ogilvie T., Designing for growth, Columbia University Press, New York 2011.

Peffers K., Tuunanen T., Rothenberger M.A., Chatterjee S., A design science research methodology for information systems research, "Journal of Management Information Systems" 2007, no. 24(3), pp. 45-77.

Rittel H.W., Webber M.M., Dilemmas in a general theory of planning, "Policy Sciences" 1973, no. 4(2), pp. 155-169.

Romme A.G.L., Making a difference: Organization as design, "Organization Science" 2003, no. 14(5), pp. 558-573.

Shangraw Jr. R.F., Crow M.M., Overman E.S., Public administration as a design science, "Public Administration Review" 1989, no. 49(2), pp. 153-158.

Simon H., The sciences of the artificial, MiT Press, Cambridge 1996.

Sobota D.R., Szewczykowski P., Design thinking jako metoda twórczości, "Filo-Sofija" 2014, no. 14(27), pp. 91-113. 
Verganti R., Design, meanings, and radical innovation: A metamodel and a research agenda, "Journal of Product Innovation Management" 2008, no. 25(5), pp. 436-456.

Weber S., Design science research: Paradigm or approach?, [in:] Proceedings of the Sixteenth Americas Conference on Information Systems, no. 214, Lima 2010.

Wszołek M., Grech M., Komentarz do wydania II, [in:] T. Brown (ed.), Zmiana przez design: Jak Design Thinking zmienia organizacje i pobudza innowacyjność, Instytut Dziennikarstwa i Komunikacji Społecznej Uniwersytetu Wrocławskiego, Wrocław 2016, s. 11-20.

\section{Abstract}

The paper concerns the methodological basis of research for creating knowledge in management sciences understood as practical sciences or design sciences. The aim of this paper is to introduce research framing in management sciences, which takes into account that the conventional approaches to management regarded as an explanatory science are not sufficient to fully examine and deal with contemporary ill-structured, complex, unambiguous and often open management and organization problems. The aim has been realized using existing knowledge within a conceptual research framework for intellectual deliberation on the presented approach.

Keywords: design, methodology, design-led approach to management, design science research, research through design 